\title{
Smart Culture of Spirulina Using Supernatant of Digested Rotten Tomato (Solanum Lycopersicum) to Produce Protein, Bio-Fuel and Bio-Electricity
}

\author{
M. Ahsan B. Habib ${ }^{1}$, Afsana Nony ${ }^{2}$, Maisha F. Orpa ${ }^{3}$ \\ 1,2,3 Department of Aquaculture, Faculty of Fisheries, Bangladesh Agricultural University, Mymensingh, Bangladesh.
}

\begin{abstract}
An experiment was conducted for the production of protein, bio-fuel and bio-electricity from the culture system of Spirulina platensis (Gomont) in supernatant of three different amount of digested rotten tomato (Solanum lycopersicum), and Kosaric Medium (KM) as control. Three different concentrations such as 25, 50 and $75 \%$ rotten tomato were allowed to digest under aeration. After 17 days, the colorless supernatant was screened and taken in $1.0 \mathrm{~L}$ conical flask with three replications. Then, Spirulina platensis was inoculated to grow in these three media (treatments) with the addition of $9.0 \mathrm{~g} / \mathrm{L} \mathrm{NaHCO} 3$ and micronutrients, and also in KM as control for a period of 14 days. The cell weight, optical density, chlorophyll a and total biomass of spirulina was attained to the maximum values when grew in KM on the 10th day of culture followed by supernatant of $50 \%$ digested rotten tomato (DRT) than in 25 and 75\% DRT culture. The chemical properties of the culture media such as pH, salinity, dissolved bio-oxygen, electric conductivity and bio-electricity were increased from first day up to 12th day of experiment. Total biomass of spirulina grown in these media had highly significant $(\mathrm{P}<0.01)$ correlation with cell weight $(\mathrm{r}=0.825)$ and chlorophyll a $(\mathrm{r}=0.866)$ of spirulina. The results showed that the growth performances of S. platensis grown in supernatant of $50 \%$ DRT was significantly $(\mathrm{P}<0.01)$ higher than that of spirulina grown in supernatant of 25 and $75 \%$ DRT. The percentage of crude protein $(55.10 \pm 0.45$ to $59.90 \pm 0.33 \%)$ of spirulina grown in supernatant of DRT was little bit higher than that of spirulina cultured in $\mathrm{KM}(58.40 \pm 0.38 \%)$. But bio-fuel in terms of crude lipids $(16.50 \pm 0.31 \%)$ of spirulina cultured in supernatant of $50 \%$ DRT was almost two and half times higher than that of spirulina grown in KM (crude lipids, $6.30 \pm 0.21 \%$ ). Bio-electricity (300 $\pm 10.20 \mathrm{mV}$ ) produced in culture of spirulina in supernatant of 50\% DRT was higher than that recorded in KM $(240 \pm 10.20 \mathrm{mV})$ followed by 75\% DRT and other media. Bio-electricity had directly and strongly significant $(\mathrm{p}<0.001)$ correlation with $\mathrm{pH}(\mathrm{r}=$ $0.812)$, dissolved bio-oxygen $(\mathrm{r}=0.832)$, salinity $(\mathrm{r}=0.788)$ and electric conductivity $(\mathrm{r}=0.856)$. Therefore, this procedure will produce huge amount of electricity in the world and will make a revolution in this field of bio-electricity production. Whole world will be benefited from the output (results) of this experiment.
\end{abstract}

KEY WORDS: Spirulina, protein, supernatant, rotten tomato, bio-fuel, bio-electricity

\section{INTRODUCTION}

Spirulina platensis is a filamentous, multicellular blue green microalgae and they are usually very small. Spirulina platensis is a cyanobacterium that has a high protein content and therefore, has high nutritional value. Spirulina contain 50-70\% protein, 10$12 \%$ carbohydrate, $6-20 \%$ fat, $7 \%$ minerals and a lot of vitamins [1,2,3]. In Aquaculture, spirulina is used as feed ingredient to improve growth, feed efficiency, carcass quality, and physiological response to disease in several species of fish. Among microalgae, spirulina contains high protein (around 60-70\%) and lipids (18-22\%). But high protein and lipids were bioaccumulated in spirulina when grown in noodles factory waste and sago waste [1,4]. Other microalgae, Chlorella, Ankistrodesmus, Scenedesmus and marine algae contain less bio-energy (Protein 30\%, lipids 10-15\%) [5,6].

Microalgae can produce bio-fuel [7] and bio-diesel [8]in aquatic environment. Microalgal fuel cells (MFCs) can use bacteria to convert the chemical energy of a particular substrate contained in wastewater into electrical energy [9]. This actually occurs when bacteria transfer electrons to an electrode through electron transport system. Recently it is proved that MFCs could provide a source of green electricity or bio-electricity by using domestic and industrial wastes to generate power [10,11]. In photosynthesis, light energy splits water molecules into oxygen, protons and electrons [12]. Biophotovoltaic (BPV) platforms developed to harvest these electrons to generate bio-electricity using ITO anodes [12]. Spirulina provides all essential nutrients without excess calories and fats. It is recommended to control obesity \& premenstrual stress, and chronic leukemia [13]. The beta carotene and other carotenoids are suggested to have role in the control of cancer in human, and enhancement of pigmentation of eggs, meats of hens 


\section{International Journal of Current Science Research and Review}

ISSN: 2581-8341

Volume 04 Issue 03 March 2021

DOI: 10.47191/ijcsrr/V4-i3-06, Impact Factor: 5.825

IJCSRR@ 2021

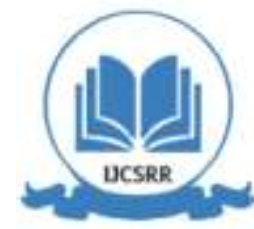

WWw.ijcsrr.org

\& birds [14,15], and coloration of ornamental fish \& fish fillet [16]. Bio-fuel can be produced from lipids of spirulina [8] and bioelectricity may be produced in culture systems of spirulina in different media using biophotovoltaic device and measured by volta meter and HEQEP CP 6014 G2 [17,12].

The quality of about $12-15 \%$ vegetable and fruits become deteriorated during storage and marketing, and are sold for human consumption producing considerable amount of waste. These rotten materials contain high carbohydrate, protein, lipid, vitamin, mineral and phosphorus. This phosphorus might help to produce high phospho-lipids and ultimately increased the amount of total lipids $[18,19]$. These wastes are easily available nationwide all the time and can be collected from the market. Therefore, the supernatant of this inexpensive waste material may be used to produce spirulina (Spirulina platensis). The present study was conducted to culture spirulina in supernatant of digested rotten tomato(Solanum lycopersicum), to record the growth performances of spirulina and to produce of single celled protein, bio-fuel as lipids and bio-electricity with the following objectives:

a) To evaluate the culture and growth performance of Spirulina platensis in supernatant of digested rotten tomato (Solanum lycopersicum);

b) To analyze protein bioaccumulation and the proximate composition of spirulina grown in different media; and

c) To estimate bio-fuel as total lipids and bio-electricity from spirulina in laboratory condition.

\section{MATERIALS AND METHODS}

The experiment was conducted in the Live Food Culture Laboratory, Dept. of Aquaculture, Bangladesh Agricultural University (BAU), Mymensingh, Basgladesh. The rotten tomato (Solanum lycopersicum) was collected from KR market in BAU campus and $400 \mathrm{~g}$ of rotten tomato were digested in 5.0 L glass jars containing $4.0 \mathrm{~L}$ distilled water for 17 days. The chemical composition of rotten tomato and supernatant of digested rotten tomato were first screened using net of $30 \mu \mathrm{m}$ mesh size to separate particles; It was filtered through Whatman filter paper of $0.45 \mu \mathrm{m}$ mesh to isolate bacteria \& suspended solids. Three different concentrations of supernatant of digested rotten tomato was used for the culture of Spirulina platensis (Table 3). Light intensity was determined by using lux-meter. Temperature was measured every day by using a Celsius thermometer and was recorded as degree Celsius. In the laboratory $12 \mathrm{~h}: 12 \mathrm{~h}=$ light: dark was provided. Kosaric medium (KM) as control (Table 4) was prepared and used for spirulina culture. Cell weight, chlorophyll $\underline{\text { a }}$ and total biomass were recorded every alternate day [20]. $\mathrm{pH}, \mathrm{dissolved} \mathrm{O}_{2}(\mathrm{mg} / \mathrm{L})$, salinity (\%), electric conductivity $(\mu \mathrm{hos} / \mathrm{cm})$ and bio-electricity $(\mathrm{mV})$ of culture media were recorded by digital meter (HEQEP CP 6014 G2). Growth of spirulina was reached at stationary phase on 12th day. Cultured spirulina was harvested before stationary phase on 10th day culture for the study of proximate composition.

Physico-chemical properties of wastes and supernatant were analysed using different equipments (HEQEP CP 6014 G2) following [20]. Proximate composition of spirulina was analysed following [21]. Spirulina was checked periodically for its purity $[22,23,24]$. Biofuel as total lipids was analysed using standard method following [8]. Bioelectricity was measured using (HEQEP CP 6014 G2) instead of biophotovoltaic device [12]. Data was analyzed using one way ANOVA followed by Duncan's New Multiple Range test (DNMRT) [25].

\section{RESULTS AND DISCUSSION}

Spirulina (Spirulina platensis) was cultured in supernatant of digested tomato (Solanum lycopersicum) in three different concentrations including Kosaric medium. The chemical composition of rotten tomato, physico-chemical properties of supernatant of digested rotten tomato are shown in Tables 1 and 2. Organic nutrients of rotten tomato were broken down in to inorganic forms (Table 2). During break down of organic nutrients into simple forms electron was discharged and transported through electron transport system (ETS) to the device [26,27]. Optical density of culture, chlorophyll a and total biomass of spirulina grown in supernatant of 50\% DRT and Kosaric medium were significantly $(\mathrm{P}<0.01)$ higher than those of spirulina cultured in other media (Table 5). Similar trend was followed in case of crude protein of spirulina grown in different media but crude lipids did not follow the trend (Table 6). High percentage of lipids (2.50 times) was bioaccumulated in spirulina during culture which grown in supernatant of $50 \%$ DRT than that of spirulina cultured in other media which helped more biofuel production (Table 6). Bioelectricity was produced from the microalgal (Spirulina platensis) culture system during the study and measured using digital meter (HEQEP CP 6014 G2). The production of bio-electricity was influenced by the production of spirulina, bio-oxygen and electrons due to splite of water molecules, electron transfer and microbial activities through electron transport system (ETS), and 


\section{International Journal of Current Science Research and Review}

ISSN: 2581-8341

Volume 04 Issue 03 March 2021

DOI: 10.47191/ijcsrr/V4-i3-06, Impact Factor: 5.825

IJCSRR@ 2021

WWw.ijcsrr.org

increase of $\mathrm{pH}$, dissolved bio-oxygen, salinity and electric conductivity (Figs. 1, 2, 3, 4 and 5) [12]. Bio-electricity had directly and strongly significant $(\mathrm{p}<0.001)$ correlation with $\mathrm{pH}(\mathrm{r}=0.812)$, oxygen $(\mathrm{r}=0.832)$, salinity $(\mathrm{r}=0.788)$ and electric conductivity $(\mathrm{r}=0.856)$ (Table 7$)$. Other growth parameters such as cell weight, chlorophyll a and total biomass had highly significant $(\mathrm{p}<0.01)$ correlation with $\mathrm{pH}$, dissolved bio-oxygen, salinity, and strongly significant $(\mathrm{p}<0.001)$ correlation with electric conductivity (Table 7). The direct correlation values indicate that the production of bio-electricity was positively influenced by these parameters [12, 26, 27]. Bio-electricity was found to produce from microalgal culture using microalgaemicrobial fuel cell technology [26]. Bio-electricity was produced from microalgal culture system in swine wastewater and measured using novel 3D electrode [9, 27]. Some researchers measured bioelectricity using the algal biophotovoltaic devices (BPV) and quantified using multimeter (Agilent U1251B) in terms of milivolts (mV) [12). Maximum power generation (1236 $\mathrm{mW} / \mathrm{m} 3$ ) was recorded when the microbe, Klebsiella oxytoca was cultured in complex substrate of palm oil mill effluent [28].

The present work was related with the production of bio-electricity from the culture system of spirulina in supernatant of digested rotten tomato which has the similarity with the findings of afore discussed findings of different authors. The rate of production of bio-electricity depends on the types of culture systems \& agroindustrial wastewater, microalgal and microbial species cultured. Bio-fuel in terms of lipids production and bio-electricity are producing from the culture media of microalgae of these agroindustrial wastes in the laboratory. It is very promising that biofuel and electricity (as bioelectricity) can be produced from microalgal cultures of rotten agro-products and waste materials in the country in huge quantity [12]. There will be no scarcity of electricity even surplus electricity and bio-fuels can be generated from microalgal culture containing supernatant of digested rotten agro-products or agro-industrial wastes in different countries of the world. It will make a revolutionary change in the field for the production of electricity in the world and also surplus electricity will be produced.

\section{CONCLUSION}

Spirulina performed higher growth in $50 \%$ digested rotten tomato media than other concentrations. It might be used as feed ingredient for fish. It could be used to produce bio-fuel from crude lipids. Bio-electricity might be generated from the culture media of spirulina. Creating awareness among people about economic and health benefits of culturing Spirulina platensis. Biofuel and bio-electricity may be produced from spirulina grown in different agro-based products. Spirulina can be used as feed ingredient to replace fish meal for fish. Government and Nongovernment organization should come forward for nationwide production industrially.

Table 1. Characteristics of rotten tomato just after collection.

\begin{tabular}{|l|l|l|}
\hline Sl. No. & Characteristics of past of rotten tomato & \\
\hline 1 & Colour & Reddish \\
\hline 2 & Odour & Little bid bad \\
\hline 3 & Structure & Semi-solid \\
\hline 4 & Temperature & $28.30-28.60^{\circ} \mathrm{C}$ \\
\hline 5 & PH & $6.30-6.45$ \\
\hline 6 & Total solids (TSS + TDS) & $1954-2135 \mathrm{mg} / \mathrm{L}$ \\
\hline 7 & Alkalinity & $132-142 \mathrm{mg} / \mathrm{L}$ \\
\hline 8 & Total N & $1.55-1.76 \mathrm{mg} / \mathrm{L}$ \\
\hline 9 & Available N (NO3-N) & $1.10-1.15 \mathrm{mg} / \mathrm{L}$ \\
\hline 10 & Available P (PO3-P) & $2.90-3.30 \mathrm{mg} / \mathrm{L}$ \\
\hline
\end{tabular}

Table 2. Physico-chemical properties of supernatant of digested rotten tomato after digestion in aerobic condition

\begin{tabular}{|l|l|l|}
\hline S1. No. & Characteristics & \\
\hline 1 & Temperature & $29.60-29.90^{\circ} \mathrm{C}$ \\
\hline 2 & Ph & $6.80-6.90$ \\
\hline 3 & Total solid (TSS + TDS) & $156-162 \mathrm{mg} / \mathrm{L}$ \\
\hline
\end{tabular}




\section{International Journal of Current Science Research and Review}

ISSN: 2581-8341

Volume 04 Issue 03 March 2021

DOI: 10.47191/ijcsrr/V4-i3-06, Impact Factor: 5.825

IJCSRR@ 2021

www.ijcsrr.org

\begin{tabular}{|l|l|l|}
\hline 4 & Alkalinity & $90-95 \mathrm{mg} / \mathrm{L}$ \\
\hline 5 & Total N & $0.90-1.10 \mathrm{mg} / \mathrm{L}$ \\
\hline 6 & Available N (NO3-N) & $0.60-0.70 \mathrm{mg} / \mathrm{L}$ \\
\hline 7 & Available P (PO3-P) & $0.80-2.85 \mathrm{mg} / \mathrm{L}$ \\
\hline
\end{tabular}

Table 3. Experimental design for Spirulina platensis culture using supernatant of three different concentrations of digested rotten tomato, and KM.

\begin{tabular}{|l|l|l|l|l|}
\hline Types of medium & Treatments & Replications & Amounts of rotten tomato (\%) & Duration of culture (days) \\
\hline $\begin{array}{l}\text { Supernatant of digested } \\
\text { rotten tomato }\end{array}$ & 1 & 3 & 25 & 14 \\
\hline & 2 & 3 & 50 & \\
\hline & 3 & 3 & 75 & \\
\hline Kosaric medium & 4 & 3 & - & 14 \\
\hline
\end{tabular}

Table 4. Composition of Kosaric medium (Modified after Zarrouk, 1996) for Spirulina platensis culture.

\begin{tabular}{|c|c|c|}
\hline Sl. No. & Chemicals/compounds & Concentration in stock solution $\mathrm{g} / \mathrm{L}$ \\
\hline 1. & $\mathrm{NaHCO}_{3}$ & 9.0 \\
\hline 2. & $\mathrm{~K}_{2} \mathrm{HPO}_{4}$ & 0.250 \\
\hline 3. & $\mathrm{NaNO}_{3}$ & 1.250 \\
\hline 4. & $\mathrm{~K}_{2} \mathrm{SO}_{4}$ & 0.50 \\
\hline 5. & $\mathrm{NaCl}$ & 0.50 \\
\hline 6. & $\mathrm{MgSO} 4.7 \mathrm{H} 2 \mathrm{O}$ & 0.10 \\
\hline 7. & $\mathrm{CaCl}_{2}$ & 0.02 \\
\hline 8. & $\mathrm{FeSO} 4.2 \mathrm{H} 2 \mathrm{O}$ & 0.005 \\
\hline 9. & $\mathrm{~A}_{5}$ micronutrient solution $^{\mathrm{a}}$ & $0.5 \mathrm{ml} / \mathrm{L}$ \\
\hline & a) $\mathrm{A}_{5}$ micronutrient solution & $\mathrm{G} / \mathrm{L}$ \\
\hline & i) $\mathrm{H}_{3} \mathrm{BO}_{4}$ & 2.86 \\
\hline & ii) $\mathrm{MnCl} 2.4 \mathrm{H} 2 \mathrm{O}$ & 1.81 \\
\hline & iii) $\mathrm{ZnSO} 4.7 \mathrm{H} 2 \mathrm{O}$ & 0.22 \\
\hline & iv) $\mathrm{CuSO}_{4} .5 \mathrm{H}_{2} \mathrm{O}$ & 0.08 \\
\hline & v) $\mathrm{MoO}_{3}$ & 0.01 \\
\hline & vi) $\mathrm{CoCl}_{2} \cdot 6 \mathrm{H}_{2} \mathrm{O}$ & 0.01 \\
\hline
\end{tabular}

Table 5. Comparison of cell weight, Chlorophyll a and total biomass of Spirulina platensis grown in supernatant of three different concentrations of digested rotten tomato (DRT), and Kosaric medium on 10th day of culture before stationary phase.

\begin{tabular}{|l|l|l|l|l|}
\hline Parameters & T1 $(25 \%$ DRT $)$ & T2 $(50 \%$ DRT $)$ & T3 $(75 \%$ DRT $)$ & T4 (KM) \\
\hline Optical density & $1.246 \pm 0.018$ & $2.026 \pm 0.09$ & $1.367 \pm 0.007$ & $2.640 \pm 0.022$ \\
\hline Cell weight $(\mathrm{mg} / \mathrm{L})$ & $1.98 \pm 0.011^{\mathrm{c}}$ & $18.859 \pm 0.47^{\mathrm{a}}$ & $14.53 \pm 0.95^{\mathrm{b}}$ & $16.44 \pm 0.031^{\mathrm{ab}}$ \\
\hline Chlorophyll $\underline{\mathrm{a}}(\mathrm{mg} / \mathrm{L})$ & $1.52 \pm 0.11^{\mathrm{c}}$ & $16.95 \pm 0.06^{\mathrm{a}}$ & $12.84 \pm 0.54^{\mathrm{b}}$ & $14.96 \pm 0.024^{\mathrm{ab}}$ \\
\hline Total biomass $(\mathrm{mg} / \mathrm{L})^{*}$ & $101.84 \pm 1.05^{\mathrm{c}}$ & $1135.65 \pm 9.56^{\mathrm{a}}$ & $860.28 \pm 1.66^{\mathrm{b}}$ & $1002.32 \pm 1.70^{\mathrm{a}}$ \\
\hline
\end{tabular}

*Total biomass = Chlorophyll a x 67 (Vonshak and Richmond, 1988). Figures in common letters do not differ significantly at $1 \%$ level of probability. 


\section{International Journal of Current Science Research and Review}

ISSN: 2581-8341

Volume 04 Issue 03 March 2021

DOI: 10.47191/ijesrr/V4-i3-06, Impact Factor: 5.825

IJCSRR@ 2021

WWw.ijcsrr.org

Table 6. Proximate composition ( $\%$ in dry matter basis) of Spirulina platensis) cultured in supernatant of three different concentrations of digested rotten tomato (DRT), and control as Kosaric medium.

\begin{tabular}{|l|c|c|c|c|}
\hline Treatments & T1 $(25 \%$ DRTM $)$ & T2 $(50 \%$ DRTM $)$ & T3 $(75 \%$ DRTM $)$ & T4 (KM) \\
\hline Moisture & $8.30 \pm 0.06$ & $8.35 \pm 0.06$ & $8.32 \pm 0.06$ & $8.33 \pm 0.06$ \\
\hline Crude protein & $56.40 \pm 0.32^{\mathrm{b}}$ & $59.90 \pm 0.33^{\mathrm{a}}$ & $55.10 \pm 0.45^{\mathrm{b}}$ & $58.40 \pm 0.38^{\mathrm{a}}$ \\
\hline Crude lipids & $12.70 \pm 0.25^{\mathrm{ac}}$ & $16.50 \pm 0.31^{\mathrm{a}}$ & $11.70 \pm 0.15^{\mathrm{bc}}$ & $6.30 \pm 0.21^{\mathrm{d}}$ \\
\hline Ash & $8.50 \pm 0.14$ & $9.35 \pm 0.15$ & $9.10 \pm 0.20$ & $13.55 \pm 0.12$ \\
\hline NFE $^{*}$ & $13.70 \pm 0.30$ & $5.55 \pm 0.17$ & $15.40 \pm 0.24$ & $12.57 \pm 0.25$ \\
\hline Crude fibre & $0.30 \pm 0.03$ & $0.25 \pm 0.04$ & $0.28 \pm 0.03$ & $0.75 \pm 0.04$ \\
\hline
\end{tabular}

$*$ NFE $($ Nitrogen Free Extract) $=100$ - (Moisture + Crude protein + Crude lipids + Ash). Figures in common letters in the same row do not differ significantly at $1 \%$ level of probability.

Table 7. Correlation coefficient (r) of cell weight, chlorophyll a \& total biomass of Spirulina platensis, and bio-electricity with $\mathrm{pH}$, dissolved bio-oxygen, salinity and electric conductivity during culture of spirulina in supernatant of digested rotten tomato.

\begin{tabular}{|l|l|l|l|l|}
\hline Parameters & $\mathrm{pH}$ & Dissolved bio-oxygen & Salinity & Electric conductivity \\
\hline Cell weight $(\mathrm{mg} / \mathrm{L})$ & $0.721^{*}$ & $0.742^{*}$ & $0.702^{*}$ & $0.795^{* *}$ \\
\hline Chlorophyll $\underline{\mathrm{a}}(\mathrm{mg} / \mathrm{L})$ & $0.728^{*}$ & $0.735^{*}$ & $0.689^{*}$ & $0.780^{* *}$ \\
\hline Total biomass $(\mathrm{mg} / \mathrm{L})$ & $0.756^{*}$ & $0.760^{*}$ & $0.696^{*}$ & $0.788^{* *}$ \\
\hline Bio-electricity $(\mathrm{mV})$ & $0.812^{* *}$ & $0.832^{* *}$ & $0.788^{* *}$ & $0.856^{* *}$ \\
\hline
\end{tabular}

df $=30, * \mathrm{P}<0.01, * * \mathrm{P}<0.001$

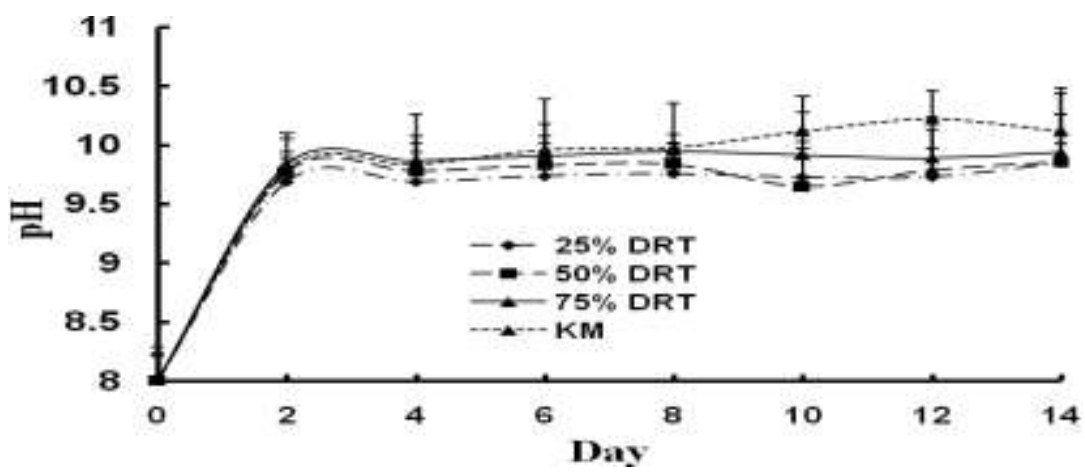

Fig.1. Mean values of $\mathrm{pH}$ during culture of Spirulina platensis in supernatant of three different digested rotten tomato (DRT), and Kosaric medium. Vertical bars represent standard errors.

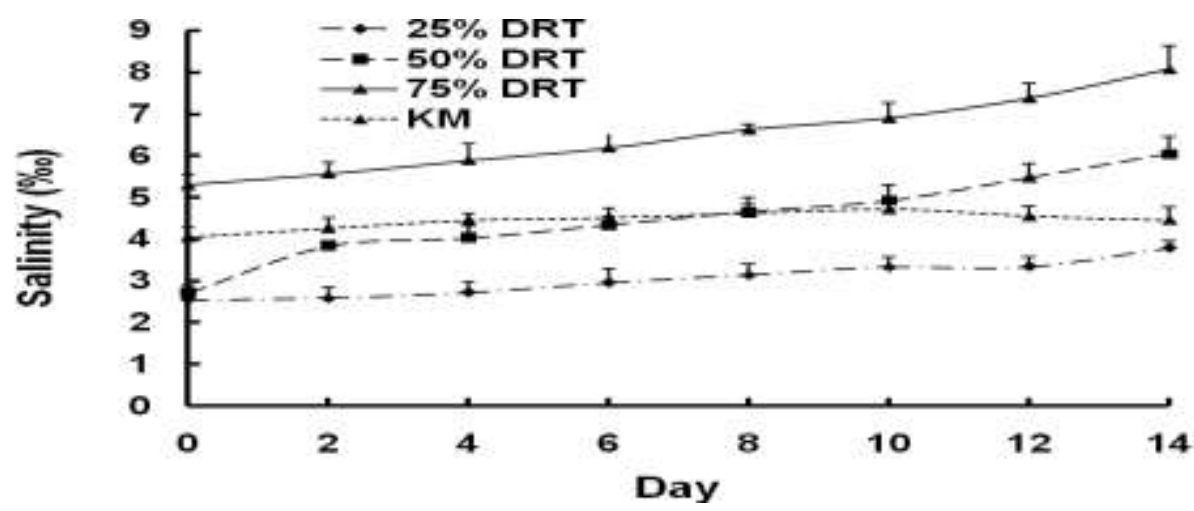

Fig. 2. Mean values of salinity during culture of Spirulina platensis in supernatant of three different digested rotten tomato (DRT), and Kosaric medium. Vertical bars represent standard errors. 


\section{International Journal of Current Science Research and Review}

ISSN: 2581-8341

Volume 04 Issue 03 March 2021

DOI: 10.47191/ijesrr/V4-i3-06, Impact Factor: 5.825

IJCSRR@ 2021

WWw.ijcsrr.org

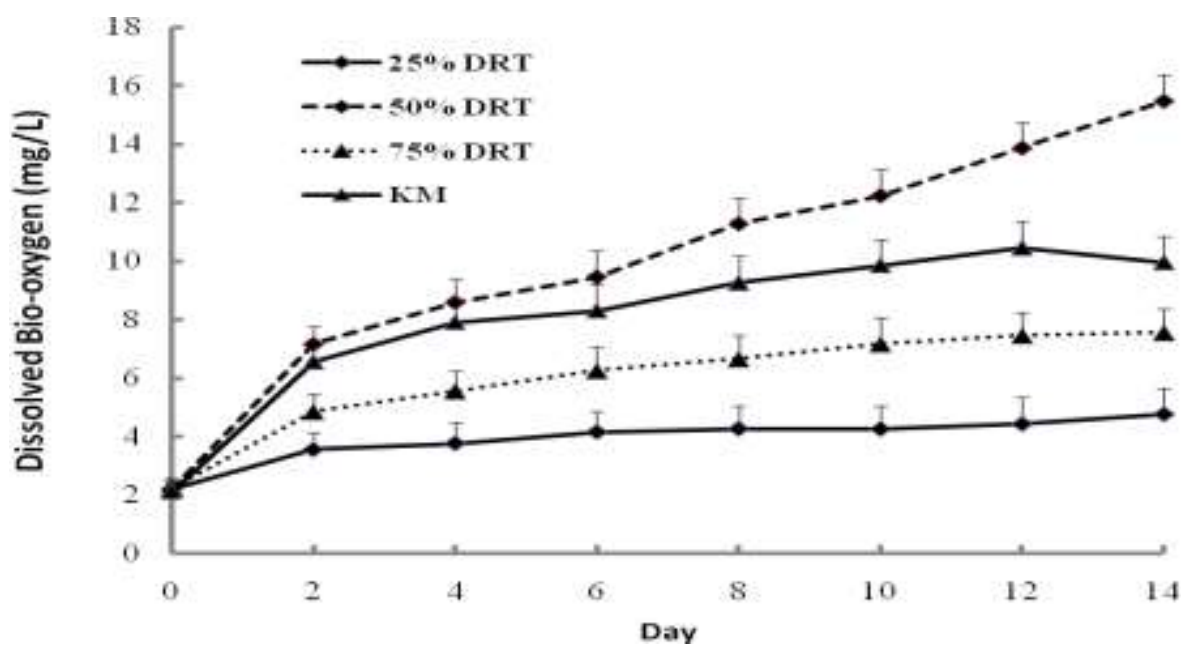

Fig.3. Mean values of dissolved oxygen $(\mathrm{mg} / \mathrm{L})$ during culture of Spirulina platensis in supernatant of three different digested rotten tomato (DRT), and Kosaric medium. Vertical bars represent standard errors.

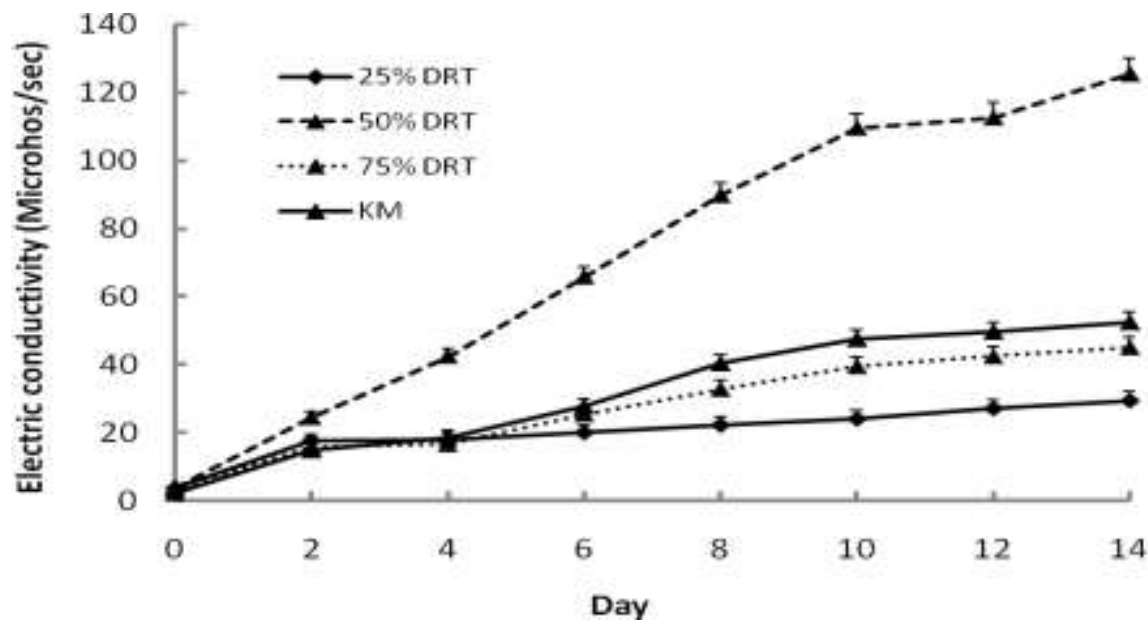

Fig. 4. Mean values of electric conductivity ( $\mu \mathrm{hos} / \mathrm{sec}$ ) during culture of Spirulina platensis in supernatant of three different digested rotten tomato (DRT), and Kosaric medium. Vertical bars represent standard errors.

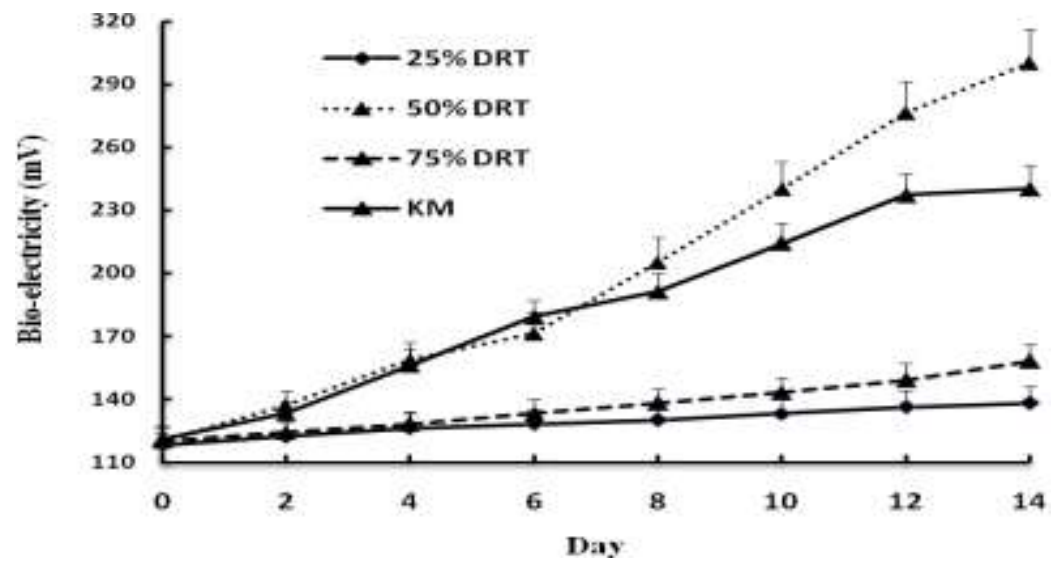

Fig. 5. Mean values of bioelectricity (mV)) during culture of Spirulina platensis in supernatant of three different digested rotten tomato (DRT), and Kosaric medium. Vertical bars represent standard errors. 
ISSN: 2581-8341

Volume 04 Issue 03 March 2021

DOI: 10.47191/ijcsrr/V4-i3-06, Impact Factor: 5.825

IJCSRR@ 2021

www.ijcsrr.org

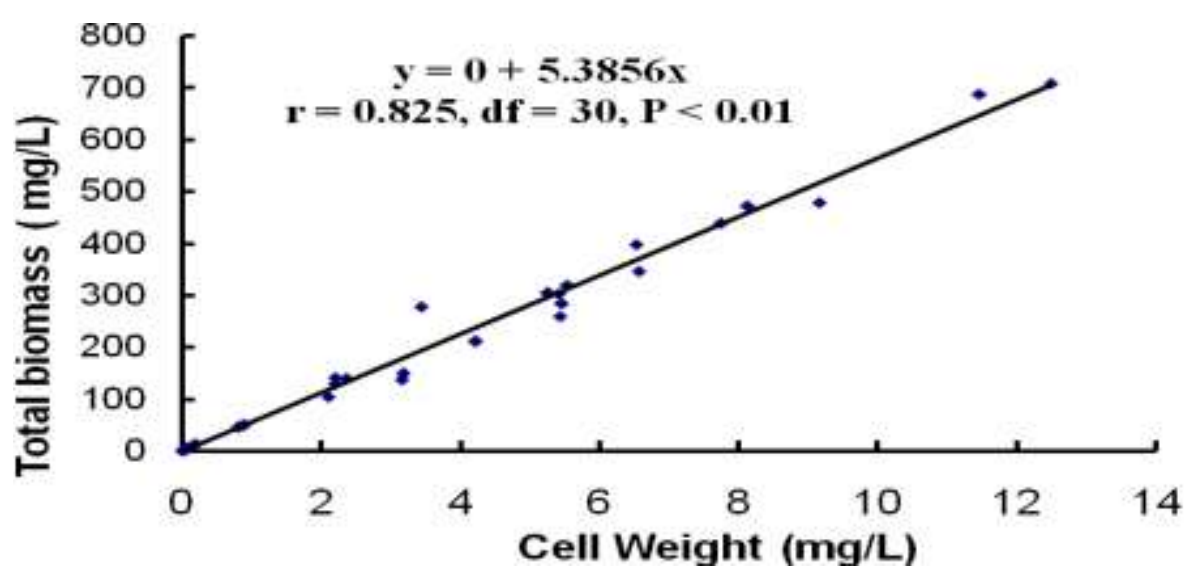

Fig.6. Correlation coefficient (r) of total biomass $(\mathrm{mg} / \mathrm{L})$ of Spirulina platensis with cell weight (mg/L) of spirulina grown in supernatant of three digested rotten tomato, and Kosaric medium.

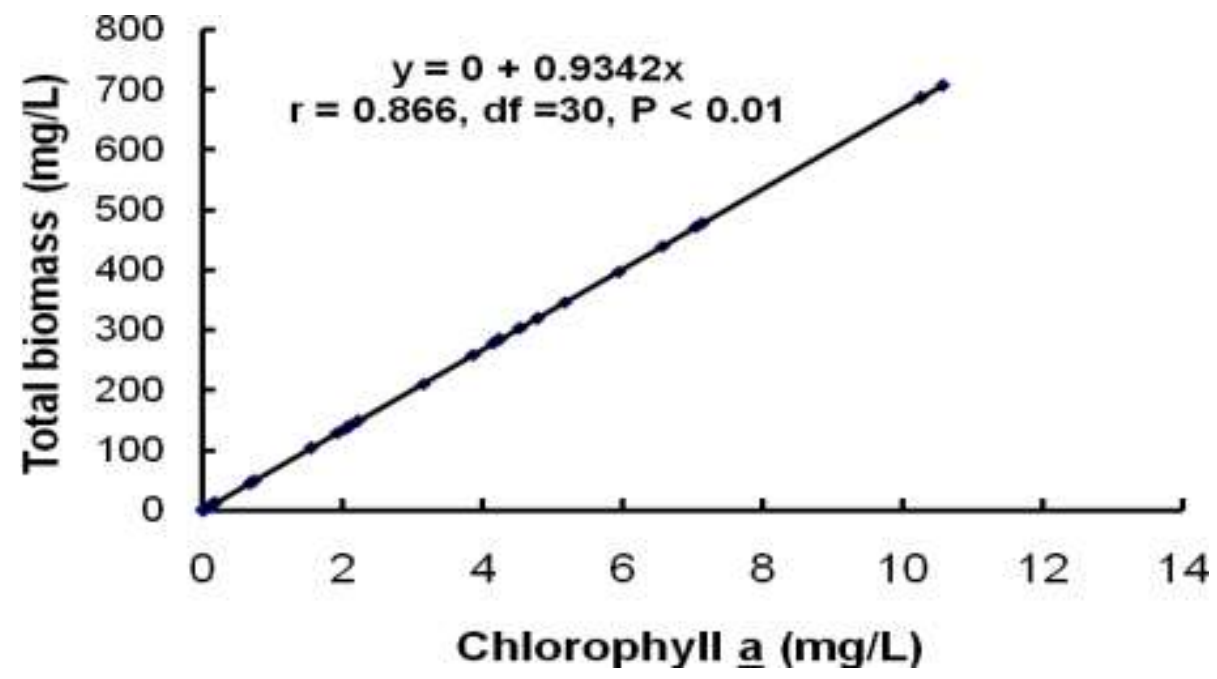

Fig. 7. Correlation coefficient $(\mathrm{r})$ of total biomass $(\mathrm{mg} / \mathrm{L})$ of Spirulina platensis with chlorophyll a $(\mathrm{mg} / \mathrm{L})$ of Spirulina grown in supernatant of three digested rotten tomato and Kosaric medium.

\section{REFERENCES}

1. Phang, S. M., Miah, M S., Chu, W. L., and Hashim, A. 2000 Spirulina culture in digested sago starch factory waste water. J. Appl. Phycol. 12, 395-400.

2. Raji, A. A., Alaba, P. A., Yusuf, H., Bakar, N. H. A., Taufek, N. M., Muin, H., Alias, Z., Milow, P., and Razak, S. A. 2018 Fishmeal replacement with Spirulina platensis and Chlorella vulgaris in African catfish (Clarias gariepinus) diet: Effect on antioxidant enzyme activities and haematological parameters. Res. Vet. Sci., 119, 67-75.

3. Sarr, S.M., Fall, J., Thiam, A., and Barry, R.O. 2019 Growth and survival of red tilapia (Oreochromis aureus x Oreochromis mossambicus) fry fed on corn and soy meal, peanut meal and fishmeal enriched with spirulina (Spirulina platensis). Int. J. Agric. Policy \& Res. 7(1), 1-9.

4. Habib, M. A. B., Parvin, M., T., Huntington, C., and Hasan, M. R. 2008 Global Review on Culture, Production and Use of Spirulina as Food for Humans and Feed for Domestic Animals and Fish. TC Huntington (Editor), Report Number GF FIRID. RA2IP02000600. Food and Agriculture Organization (FAO) of United Nations, Rome, Italy. 


\section{International Journal of Current Science Research and Review}

ISSN: 2581-8341

Volume 04 Issue 03 March 2021

DOI: 10.47191/ijesrr/V4-i3-06, Impact Factor: 5.825

IJCSRR@ 2021

WWW.ijcsrr.org

5. Muys, M., Sui, Y., Schwaiger, B., Lesueur, C., Vandenheuvel, D., Vermier, P., and Vlaeminck, S.E. 2019 High variability in nutritional value and safety of commercially available Chlorella and Spirulina biomass indicates the need for smart production strategies. Biores. Tech. 275,247-257.

6. Louhasakul, Y., Cheirsilp, B., Maneerat, S., Prasertsan, P. 2018 Direct transesterification of oleaginous yeast lipids into biodiesel: Development of vigorously stirred tank reactor and process optimization. Biochem. Eng. J. 137,232-238.

7. Harris, J., Viner, K., Champagne, P., and Jessop, F. 2018 Advances in microalgal lipid extraction for biofuel production: A review. Biofuels. Bioprod. Bioref, 12,1118-1135.

8. Soydemir, G., Keris-Sen, U. D., Sen, U., and Gurol, M. D. 2015 Biodiesel production of mixed microalgal culture grown in domestic wastewater. Bioprocess Biosystem Eng. 39: 45-51.

9. Idris, S. A., Esat, F. N., Rahim, A. A. A., Zahin, W.A., Ruzlee, R.W., and. Razali, W. M. Z. 2016 Electricity generation from the mud by using microbial fuel cell. MATEc Web of Conference, 6902001.

DoI: 10:1051,matEcconf/20166902001.

10. Hernández-Fernández, F.J., de los Ríos, A. P., Salar-García, M. J., Ortiz-Martínez, V.M., Lozano-Blanco, L. J., Godínez, C. and Quesada-Medina, J. 2015 Recent progress and perspectives in microbial fuel cells for bioenergy generation and wastewater treatment. Fuel Proc. Tech. 138, 284-297.

11. Liu, W., Cheng, S., Sun, D., Huang, H., Chen, J., and Cen, K. 2015 Inhibition of microbial growth on air cathodes of single chamber microbial fuel cells by incorporating enrofloxacin into the catalyst layer. Biosensors \& Bioelectronics 72 , 44-50.

12. Thong, C.H., Phang, S. M., Ng, F.L., Periasamy, V., Ling, T. C., Yunus, K., and Fisher, A. C. 2019 Effect of different irradiance levels on bioelectricity generation from algal biophotovoltaic (BPV) devices. Energy Sci. Eng. Doi: 10.1002/ ese3. 414.

13. Subhashini J, Mahipal, S. V. K., Reddy, M. C., Reddy, M. M., Rachamallu, A., and Reddanna, P. 2004 Molecular mechanisms in C-Phycocyanin induced apoptosis in human chronic myeloid leukemia cell line-K562. Biochem. Pharma. 68, 453-462.

14. Alvarenga, R. R., Rodrigues, P.B., de Souza. Cantarelli, V., Zangeronimo, M.G., de Silva Jứnior, J.W., de Silva, L. R., dos Santos, L. M., and Pereira. L.J. 2011 Energy values and chemical composition of spirulina (Spirulina platensis) evaluated with broilers. Revista Brasileira de Zootecnia. 40(5), 992-996.

15. Zahroojian, N., Moravej, H., and Shivazad, M. 2013 Effect of dietary marine algae (Spirulina platensis) and production performance of laying hens. J. Agric. Sci. Tech. 15, 1353-1360.

16. Rosas, V. T., Manserrat, J. M., Bassonart, M., Magnone, L., Romano, L. A., and. Tesser, M. B. 2019 Comparison of ßcarotene and spirulina (Spirulina platensis) in mullet (Mugil liza) diets and effects on antioxidant performance and fillet colouration. J. Appl. Phycol. Doi:org/101007/s10811-019-01773-1.

17. Syaifudin, N., Nurkholis, R., Handika, and Setyobudi, R. H. 2018 Formulating interest subsidy program to support development of electricity generation from palm oil mill effluent (POME) biomass: an Indonesian case study. MATEC Web Conferences, 164, pp. 1-9.

18. Lu, J., and Takeuchi, T. 2004 Spawning and egg quality of tilapia Oreochromis niloticus fed solely on raw Spirulina throughout three generation. Aquaculture 23(4), 625-640.

19. Habib, M. A. B., and Kohinoor, A. H. M. 2018 Culture and production of house fly larvae and spirulina using poultry waste and their use as food for catfish post-larvae. Report on Advanced Research. Grants for Advanced Research in Education, Secondary and Higher Education Division, Ministry of Education, Government of the Peoples' Republic of Bangladesh, Vol. 2, Chapter 2, pp. 66-70.

20. Clesceri, L. S., Greenberg, A. E., and Trussell, R. R. 1989, Standard Methods for the Examination of Water and Wastewater. American Public Health Association, American Water Works Association and Water Pollution Control Federation. 17th Edn., 1015 Washington D.C.

21. Horwitz, W. (ed.). 1984 Official methods of Analysis of the Association of Official Analytical chemists. 14th Edn., Association of Official Analytical Chemists, washington D.C. 


\section{International Journal of Current Science Research and Review}

ISSN: 2581-8341

Volume 04 Issue 03 March 2021

DOI: 10.47191/ijesrr/V4-i3-06, Impact Factor: 5.825

IJCSRR@ 2021

22. Bold, H. C., and Wynne, M. J. 1978 Introduction to the Algae, Structure and Reproduction. 2nd edition, Prentice-Hall, Inc., Englewood Cliffs, New Jersey.

23. Yamaguchi, T. 1992 Plankton Algae in Taiwan (Formosa). Uchida Rokakuho, Tokyo.

24. Phang, S.M., and Chu, W.L. 1999 University of Malaya Algae Culture Collection (UMACC). Catalogue of Strain. Institute of Postgraduate Studies and Research, University of Malaya, Kuala Lumpur, Malaysia.

25. Zar, J. H. 1984 Biostatistics. Prentice-Hall, Inc., Englewood Cliffs, New Jersey.

26. da Costa, C., and Hadiyanto, H. 2018 Boielectricity production from microalgae-microbial fuel cell technology (MMFC). MATEC Web of Conferences 156, 01017 (2018) https:// doi.org/10.1051/matecconf/201815601017.

27. Lai, M. F., Lin, J. H., Lou, C. W., and Lin, C. W. 2016 Electricity generation with the novel 3D electrode from swim wastewater in a dual-chamber microbial fuel cell. MATEC Web of Conferences, 01007.

Doi: 10.1051/matecconf/2016667 701007

28. Islam, M.A., Rahman, M., Yusuf, A., Cheng, C.K., Wai. W.C. 2016 Performance of Klebsiella oxytoca to generate electricity from POME in microbial fuel cell. MATEC Web of Conference, 38, 03004. Doi: 10.1051/matecconf/2016 3803004.

Cite this Article: M. Ahsan B. Habib, Afsana Nony, Maisha F. Orpa (2021). Smart Culture of Spirulina Using Supernatant of Digested Rotten Tomato (Solanum Lycopersicum) to Produce Protein, Bio-Fuel and Bio-Electricity. International Journal of Current Science Research and Review, 4(3), 186-194 